\title{
Minimnya Budaya Disiplin dan Kerja Keras dalam Bekerja Khususnya dalam Ruang Lingkup Koperasi di Indonesia pada Era Industri 4.0
}

\author{
${ }^{1}$ Naufal Zimly Assiddiq \\ ${ }^{1}$ Universitas Komputer Indonesia
}

Article history

Received: 20 September 2021

Revised: 08 Oktober 2021

Accepted: 09 November2021

*Corresponding Author:

Naufal Zimly Assiddiq

Universitas Komputer

Indonesia

Email:

naufal.21220212@mahasis

wa.unikom.ac.id

\begin{abstract}
The culture of discipline and hard work is very important in the lives of all of us, especially in the world of work. Because the culture of discipline and hard work plays a very important role in advancing employee welfare and improving the quality of the company. In this case the cooperative as written and explained in Law number 25 of 1992 article 3, namely promoting the welfare of members. Currently, in Indonesia there are still many people who have not made a culture of discipline and hard work as a benchmark or benchmark in carrying out their work. Like going from home to office just to fill attendance, playing truant while at work and so on. Then in cooperatives such as lack of coordination and cooperation between members and administrators so that the results of the cooperatives that are run are less than optimal and not in accordance with the target. Therefore, the purpose of writing this article is to find solutions and suggestions for the lack of a culture of discipline and hard work of Indonesian cooperatives in the industrial era 4.0 .
\end{abstract}

Keywords: Discipline, Hard Work, Culture, Cooperative

\section{PENDAHULUAN}

Latar belakang dari penelitian ini adalah karena masih banyaknya para pekerja atau karyawan disuatu koperasi, organisasi, ataupun perusahaan di indonesia pada era industri 4.0 yang belum menerapkan serta mengaplikasikan budaya disiplin dan bekerja keras dalam pekerjaannya. Karena pada dasarnya budaya disiplin dan sikap bekerja keras itu muncul pada diri sendiri. Bagaimana kesadaran seseorang akan pentingnya rasa disiplin dan kerja keras bagi dirinya. Dan kesadaran akan hal tersebut menjadi penting karena perusahaan yang berhasil itu sangat dipengaruhi oleh sumber daya manusia yang dia miliki. Maka jika produktifitas suatu perusahaan ingin meningkat maka kinerja karyawan pun harus meningkat, sebaliknya semakin turun kinerja karyawan maka produktifitas perusahaan tersebut juga akan menurun (Moehiriono, 2009).

Keberhasilan kinerja pada suatu organisasi sangat bergantung pada individu yang berada pada organisasi tersebut meskipun berasal dari berbagai latar belakang budaya yang berbeda. Perusahaan tidak akan berkembang jika tidak memperkokoh fondasinya, maksud dari memperkokoh fondasi tesebut yaitu memperkuat serta memperbaiki organisasi atau perusahaan dimulai dari fondasinya yaitu para karyawan sehingga organisasi dan perusahaan tersebut dapat lebih maju dari sebelumnya. Rumusan masalah ataupun pertanyaan pertanyaan yang disampaikan pada penelitian ini diantaranya adalah mengapa belum meratanya budaya disiplin di lingkungan pekerja khususnya dalam ruang lingkup koperasi di indonesia di era industri 4.0, mengapa sikap bekerja keras belum menjadi patokan serta 
tolak ukur dalam menjalankan pekerjaannya, bagaimana cara agar budaya disiplin dan sikap kerja keras dalam bekerja dapat dijalankan oleh para pekerja dengan senang hati juga tanpa paksaan, dan pertanyaan - pertanyaan lainya yang berkaitan dengan budaya disiplin dan bekerja keras khususnya pada ruang lingkup koperasi di indonesia di era industri 4.0.

Tujuan dari penelitian ini yaitu untuk mengetahui sejauh mana budaya disiplin dan bekerja keras di indonesia pada ruang lingkup koperasi sehingga dapat menemukan solusi dan saran dari minimnya kesadaran akan budaya disiplin dan kerja keras koperasi indonesia di era industri 4.0 .

\section{TINJAUAN PUSTAKA \\ Budaya Disiplin}

Disiplin merupakan perilaku atau sifat seseorang yang menunjukkan pada sikap kepatuhan, keteraturan, ketertiban dan kesetiaan pada kebijakan serta peraturan suatu organisasi atau perusahaan dan menjunjung tinggi nilai - nilai norma sosial aturan yang berlaku. Bagi perusahaan sikap atau perilaku disiplin merupakan suatu hal yang sangat penting. Karena dengan hadirnya sikap disiplin di lingkungan kerja akan menjamin kelancaran pelaksanaan kerja perusahaan, sehingga dapat memperoleh hasil yang maksimal. Kemudian bagi pekerja atau karyawan, disiplin dalam bekerja akan menambah semangat dalam pekerjaannya serta memberikan suasana kerja yang menyenangkan di lingkungan perusahaan. Berikut adalah definisi disiplin dalam bekerja menurut beberapa sumber :

Menurut Sutrisno (2009), Disiplin kerja merupakan perilaku yang sesuai dengan peraturan dan prosedur kerja yang ada. atau disiplin adalah sikap, tingkah laku dan perbuatan yang sesuai dengan peraturan dari organisasi baik yang tertulis maupun yang tidak tertulis.

Hasibuan (2003) berpendapat bahwa disiplin kerja adalah kesadaran dan kesediaan seseorang menaati semua peraturan dan norma - norma sosial yang berlaku. Kesadaran adalah sikap seseorang yang diatur tanpa paksaaan. Semua hal dilakukan dengan sadar dan atas rasa tanggung jawab, kesediaan adalah suatu sikap dan tindakan dalam melaksanakan peraturan, baik aturan yang tertulis maupun tidak.

Sementara itu, menurut Sastrohadiwiryo (2003) disiplin kerja adalah menghormati, menghargai, patuh dan taat terhadap peraturan - peraturan, baik yang tertulis maupun tidak tertulis serta sanggup menjalankannya dan tidak mengelak untuk menerima sanksi sanksinya apabila melanggar pada tugas dan aturan yang diberikan kepadanya.

Hodges dalam (Yuspratwi, 1990) mengatakan bahwa disiplin dapat diartikan sebagai sikap seseorang atau kelompok yang berniat untuk mengikuti aturan - aturan yang telah ditetapkan, yang bersangkutan dengan pekerjaan, disiplin adalah suatu sikap dan tingkah laku seseorang yang menunjukan ketaatan terhadap peraturan organisasi.

Lumentut \& Dotulong (2015: 76) mengatakaan bahwa disiplin umumnya diartikan sesuai dan ketaatan pada peraturan - peraturan atau ketentuan-ketentuan aturan yang berlaku dilingkungan organisasi masing - masing, jika terdapat karyawan dan dia tidak mematuhi peraturan dan ketentuan yang berlaku di lingkungan kerja, berarti tindakan karyawan tersebut dapat dikategorikan sebagai tindakan yang melanggar aturan.

Sedangkan, Katiandagho, Mandey, \& Mananeke (2014: 1594) menyatakan bahwa sikap disiplin juga merupakan modal aturan yang diperlukan untuk mencapai tujuan yang diinginkan. Keberadaan disiplin kerja diperlukan dalam suatu perusahaan, karena dengan suasana tersebut sebuah organisasi atau instansi akan bisa melaksanakan program-program kerjanya sesuai sasaran yang ingin dicapai.

\section{Kerja Keras}

Kerja keras juga merupakan suatu hal yang sangat penting dalam menjalankan 
pekerjaan. Karena ketika sikap atau perilaku disiplin kemudian ditopang dengan kerja keras, maka kinerja dan motivasi bekerja dari karyawan tersebut akan lebih meningkat. kemudian perusahaan pun akan mendapatkan hasil yang memuaskan dari kinerja para karyawannya. Begitupun sama ketika berada di lingkungan koperasi. Ketika semua pengurus dan anggota koperasi menerapkan sikap atau perilaku disiplin dan kerja keras dalam membangun serta mengembangkan koperasinya, maka koperasinya pun akan mendapatkan hasil yang memuaskan dan akhirnya koperasi tersebut dapat mensejahterakan anggotanya sesuai dengan tujuan koperasi. Sebelum lebih jauh mari kita bahas apa sebenarnya makna atau defiisi dari kerja keras.

Kerja keras merupakan usaha yang dilakukan oleh seseorang dengan sekuat tenaga dan sepenuh hati untuk mendapatkan dan mencapai hasil yang maksimal. Maksud dari berusaha disini yaitu berusaha untuk tujuan positif dengan adil dan jujur. Berusaha sesuai dengan kemampuan masing - masing dan jangan terlalu memaksakan diri, sebab jika seseorang berusaha untuk bekerja keras dan terlalu memaksakan diri maka hasilnya akan kurang maksimal. Kerja keras juga merupakan suatu cara bila mana ingin mencapai sesiuatu. Dan yang terpenting adalah bekerja keras dalam hal yang positif bukan bekerja keras dalam hal negatif atau dapat merugikan orang lain. Berikut adalah definisi kerja keras dalam bekerja menurut beberapa sumber :

Menurut Mustari (2011) Kerja keras adalah prinsip perilaku yang menunjukkan benar - benar dalam mengatasi berbagai hambatan untuk menyelesaikan tugas (belajar atau pekerjaan) dengan sebaik-baiknya.

Kesuma, dkk (2011) menyatakan bahwa kerja keras adalah suatu istilah yang melingkupi suatu upaya yang terus dilakukan (tidak pernah menyerah) dalam menyelesaikan pekerjaan atau yang menjadi tugasnya sampai tuntas. Kerja keras bukan berarti bekerja sampai tuntas lalu berhenti, prinsip yang dimaksud adalah mengarah pada visi besar, prinsip yang harus dicapai untuk manusia dan lingkungannya.

Sedangkan, Narwanti (2011) menyatakan bahwa kerja keras adalah perilaku yang menunjukkan upaya sungguh-sungguh dalam mengatasi hambatan belajar dan tugas, serta menyelesaikan tugas dengan sebaik-baiknya.

Yaumi (2014) menjelaskan bahwa kerja keras diartikan sebagai perilaku individu yang menunjukkan suatu prinsip usaha sungguh-sungguh dalam mengatasi berbagai hambatan, baik hambatan dalam belajar maupun hambatan dalam menyelesaikan berbagai tugas dalam kehidupannya sebaik-baiknya.

Dari pemaparan diatas sekali lagi bahwa sikap atau perilaku disiplin dan kerja keras sangatlah penting dalam dunia pekerjaan apalagi sekarang di era industri 4.0 yang dimana persaing - pesaing baru banyak bermunculan dan juga teknologi yang terus berkembang tiada hentinya. Maka kedua sikap inilah yang harus kita lakukan agar tidak tertinggal dengan yang lainnya. Hasil studi (Ferdinand, 2004) menyatakan bahwa sumber daya manusia dalam melakukan pekerjaanya ditentukan oleh sikap kerja prinsip positif yang berasal dari sikap kerja keras, sikap kerja cerdas serta sikap kerja agresif (pekerja keras, operasi cerdas, persetujuan). Begitu pun pada penerapannya di lingkungsn koperasi. Bagaimana caranya agar pengurus serta anggota dapat disiplin dan kerja keras juga bekerja dengan cerdas agar nantinya dapat menghasilkan hasil yang maksimal untuk mensejahterakan semua anggota koperasinya. Lalu seperti apakah kriteria ketika seorang pegawai atau pekerja tersebut sudah bisa dikatakan disiplin dan kerja keras. Menurut (setiawan dan Kartika, 2014:1477) ada beberapa indikator - indikator untuk mengukur kinerja seseorang. Pertama, penyelesaian kerja. maksudnya dia sudah bisa mengelola waktu kerjanya dengan baik dan juga mampu menyelesaikan pekerjaannya dengan tepat. Kedua, kesesuaian pada jam kerja. Maksudnya dia taat dan patuh pada peraturan - peraturan yang berlaku seperti ketepatan waktu masuk dan pulang kerja. Ketiga, kehadiran. Maksudnya ketika tingkat kehadiran seorang pegawai 
baik, berarti dia sudah bisa dikatakan sebagai orang yang disiplin dan kerja keras. Keempat, kerjasama. Maksudnya dia sudah bisa bekerjasana dengan pegawai lainnya dalam menyelesaikan suatu pekerjaan yang telah ditentukan dan mencapai hasil yang memuaskan.

\section{METODE PENELITIAN}

Metode yang digunakan pada penelitian ini yaitu bersifat kualitatif dengan metode studi literatur. Penelitian kualitatif yaitu jenis penelitian yang temuan-temuannya tidak diperoleh melalui prosedur statistik ataupun bentuk hitungan lainnya dan berusaha untuk menafsirkan dan memahami makna pada suatu peristiwa interaksi tingkah laku manusia dalam situasi tertentu menurut perspektif peneliti sendiri. Penelitian kualitatif juga merupakan penelitian yang bersifat deskriptif dan cenderung menggunakan analisis. Penelitian kualitatif juga dikenal sejak tahun 1960-an dan sering disebut juga sebagai metode alternatif. Metode ini tidak menggunakan aturan pertanyaan rinci, tapi dimulai dengan pertanyaan umum kemudian meruncing dan mendetail. Metode kualitatif ini memperlakukan partisipan sebagai bukan objek sehingga partisipan berharga karena informasi dari mereka sangat bermanfaat. Penelitian kualitatif menurut para ahli sebagai berikut :

Menurut Saryono (2010) penelitian kualitatif adalah penelitian yang digunakan untuk menemukan, menggambarkan, dan menjelaskan kualitas atau keistimewaan dari aturan pengaruh sosial yang tidak dapat mengukur atau menggambarkan melalui pendekatan kuantitatif.

Sugiyono (2011) menjelaskan metode penelitian kualitatif adalah metode penelitian dimana memerintah berlandaskan pada filosofi postpositivisme, digunakan untuk meninjau kondisi obyek aturan yang diatur alamiah, lawannya eksperimen, yang penelitinya adalah sebagai instrumen kunci,

Pengambilan sampel dilakukan secara purposive dan snowball, teknik yang digunakan dengan triangulasi (gabungan), analisis data bersifat induktif atau kualitatif, dan hasil penelitian kualitatif lebih menekankan pada generalisasi.

Creswell (2008) mendefinisikan metode penelitian kualitatif sebagai suatu pendekatan atau pemahaman untuk memahami suatu gejala sentral. Untuk memahami gejala tersebut, peneliti mewawancarai peserta penelitian atau partisipan dengan mengajukan pertanyaan tentang aturan umum dan agak luas. Informasi kemudian dikumpulkan dalam kata maupun teks. Kumpulan informasi tersebut kemudian dianalisis. Dari peneliti hasil analisis tersebut kemudian dijabarkan dengan penelitian- penelitian ilmuwan lain yang dibuat sebelumnya. Dan hasil akhir penelitian kualitatif dalam bentuk laporan tertulis.

Metode studi literatur adalah kegiatan yang mengukuti aturan - aturan dengan metode pengetahuan pustaka, membaca dan mencatat, serta mempelajari bahan penelitian (Zed, 2008:3). Pengumpulan pengetahuan pustaka merupakan kegiatan yang diwajibkan pada sebuah penelitian, terlebih dahulu pada penelitian akademik yang bertujuan untuk mengembangkan aspek manfaat praktis maupun aspek teoritis. Pengumpulan pengetahuan kepustakaan dilakukan oleh setiap peneliti dengan tujuan utamanya yaitu mencari dasar pijakan / fondasi untuk memperoleh serta membangun landasan teori, kerangka berpikir, dan dugaan - dugaan atau sering disebut juga dengan hipotesis penelitian. Sehingga para peneliti dapat mengalokasikan, menggelompokkan, mengorganisasikan, dan menggunakan variasi dalam bidangnya. Dengan melakukan pengumpulan data kepustakaan, para peneliti mempunyai pendalaman yang lebih luas juga mendalam terhadap masalah - masalah yang hendak diteliti.

\section{HASIL DAN PEMBAHASAN}


Setelah kita mengetahui apa - apa saja yang menjadi pokok bahasan di dalam penelitian ini, kemudian saya meninjau dan menganalisis dari beberapa sumber yang berkaitan dengan budaya disiplin dan kerja keras koperasi Indonesia di era industri 4.0. Harus kita akui bahwa keberadaan koperasi di Indonesia sangatlah penting untuk perkembangan ekonomi nasional, oleh sebab itu mereka harus bisa mengembangkan dan memberdayakan koperasinya juga harus memiliki suatu kebijakan yang cerdas yaitu harus mencerminkan kepada prinsip dan nilai koperasi sebagai wadah untuk bersama - sama berusaha memenuhi aspirasi dan kebutuhan ekonomi anggotanya, agar nantinya dapat menjadi koperasi yang sehat, tangguh dan juga kuat ketika menghadapi perkembangan ekonomi nasional dan juga ekonomi global yang semakin banyak tantangan dan semakin dinamis. Kemudian juga ketika sebuah koperasi membuat suatu kebijakan, maka haruslah kebijakan tersebut melibatkan anggota, sehingga nantinya dapat mengeluarkan hasil yang menguatkan serta dapat mengembangkan koperasi untuk kedepannya.

Di Indonesia sendiri setelah saya saya lihat dari beberapa sumber, ternyata masih banyak koperasi yang belum menerapkan sikap disiplin dan kerja keras. Maka dari itu untuk menuju pada tujuan - tujuan koperasi yang telah disebutkan, salah satunya dengan menerapakan budaya disiplin dan kerja keras. mengapa sikap bekerja keras belum menjadi patokan serta tolak ukur dalam menjalankan pekerjaannya ?. setelah dianalisis dari beberapa sumber, ada beberapa faktor yang membuat mengapa sikap sikap kerja keras masih belum menjadi patokan serta tolak ukur dalam menjalankan pekerjaannya.

Diantaranya menurut (Raharjo, 2011) pertama Masih banyaknya pekerja yang hanya lulusan SD, SMP, SLTA, Persoalan ini masih menjadi masalah yang belum juga terselesaikan di negara Indonesia. Dan persoalan ini juga yang masih membuat Indonesia berada di titik rendah dan sulit untuk bersaing dengan negara lain. Bukan berarti lulusan pada tingkatan - tingkatan tersebut menjadikan mereka dipandang sebelah mata oleh yang lainnya. Akan tetapi, pengembangan sumber daya manusia (SDM) yang berkelanjutan merupakan kebutuhan yang mutlak perlu untuk di masa yang akan datang. Pendidikan yang berkelanjutan dapat membuat seseorang berfikir akan pentingnya disiplin dan kerja keras di dalam kehidupannya. Contohnya seperti ketika di sekolah ataupun di kampus, ketika kita mendapatkan tugas dari para guru atau dosen. Maka, sebagai murid dan mahasiswa kita wajib mengerjakan tugas yang diberikan tersebut. Dari situlah pasti akan muncul rasa tanggung jawab untuk mengerjakan tugasnya sehingga muncul pula sikap disiplin dan kerja keras dalam pribadi orang tersebut, sehinngga motivasinya pun juga meningkat. Dari contoh sikap tersebut maka kita bisa membiasakan diri kita untuk berlaku disiplin dan kerja keras dari masa sekolah hingga kita bekerja ketika sudah dewasa nanti.

Kedua Sejarah bangsa Indonesia, Sebenarnya masyarakat Indonesia pada masa nenek moyang terdahulu adalah orang - orang yang rajin serta terampil. Akan tetapi pada masa berikutnya karena keberadaan sumber daya alam di Indonesia yang sangat melimpah juga dengan iklim yang hanya memiliki dua musim yaitu musim kemarau dan musim hujan. Membuat sikap dan kebiasaan masyarakat Indonesia mengalami penurunan. Hal ini terjadi karena sumber daya alam Indonesia yang sangat melimpah membuat masyarakat tidak pelu kerja begitu keras untuk memenuhi kebutuhannya. Kerena perilaku inilah yang mengakibatkan Indonesia belum menjadi negara yang bisa dikatakan maju.

Ketiga Budaya, Pada persoalan ini kita bisa lihat pada bidang politik dimana ketika seseorang ingin untuk duduk pada suatu jabatan tertentu dia harus menyogok, mereka lebih mengutamakan jabatan dan kekuasaan dari pada prestasi, pelayanan publik dan juga produktivitas (Manullang, 2010). Tapi bukan berarti semua yang memiliki profesi di bidang politik mempunyai perilaku seperti itu, namun ada saja oknum - oknum yang memang memanfaatkan uang demi meduduki suatu jabatan. Tentunya perilaku - perilaku seperti ini yang harus kita hilangkan, karena bila budaya seperti ini terus berlanjut maka sangat 
memungkinkan untuk terus dilakukan pada generasi di masa yang akan datang.

Keempat, Pelayanan kebutuhan masyarakat, Setiap orang pasti ingin bisa memenuhi kebutuhannya. Maka untuk memenuhi kebutuhannya tersebut mereka harus menjadi orang - orang yang handal dalam berbagai macam seperti keterampilan, kedisiplinan, pengetahuan dan sikap pada setiap pekerjaannya. Maka agar kualitas setiap orang atau pekerja meningkat maka haruslah di dukung oleh fasilitas - fasilitas yang memadai. Karena semakin lengkap fasilitas yang disediakan akan mempengaruhi pada kualitas kerja seseorang untuk mencapai hasil yang diinginkan.

Lalu bagaimana cara agar budaya disiplin dan sikap kerja keras dalam bekerja khususnya pada lingkungan koperasi dapat dijalankan oleh para pekerja dengan senang hati juga tanpa paksaan?. Setelah menganalisis dari beberapa sumber yang saya lihat. ada beberapa cara atau tahapan yang bisa dilakukan agar dapat meningkatkan budaya disiplin dan kerja keras dalam bekerja khususnya di lingkungan koperasi diantaranya;

Pertama, pemberian motivasi dan pelatihan. Mengapa perlu untuk memberikan motivasi dan pelatihan, karena dengan memberikan motivasi yang berkaitan dengan disiplin dan kerja keras kepada karyawan ataupun pekerja setidaknya bisa meningkatkan kesadaran diri para karyawan agar mengetahui akan pentingnya disiplin dan kerja keras sehingga mempermudah dalam menjalankan pekerjaannya. Jika di contohkan seperti mengadakan penyuluhan dan pemberian motivasi oleh pengurus koperasi kepada anggota - anggotanya. Dengan begitu selain dapat meningkatkan kesadaran masing - masing juga dapat menguatkan Kembali silaturahmi antar pengurus dan anggota koperasi.

Kedua, keteladanan pemimpin. Hal ini di rasa perlu karena pemimpin merupakan contoh bagi bawahannya. Maka dari itu hendaknya seorang pemimpin harus mempunyai sikap disiplin dan kerja keras agar nantinya bisa ditiru oleh bahawan - bawahannya.

Ketiga, membuat aturan yang pasti. Maksudnya ketika tidak adanya aturan yang pasti maka tidak ada yang dapat dijadikan sebagai pegangan oleh karyawan. Untuk itu sangatlah penting sebuah peraturan bagi perusahaan ataupun koperasi.

Keempat, adanya pengawasan. Fungsi dari pengawasan ini adalah untuk memantau karyawan agar melaksanakan pekerjaannya dengan baik dan benar. Dan jika ada karyawan yang menyimpang atau melakukan sesuatu yang tidak sesuai dengan tujuan yang diharapkan maka dapat diambil tindakan sesuai dengan keputusan bersama.

Kelima, perhatian antar karyawan. Ini juga menjadi pentimg karena kita sesama manusia harus saling mengingatkan apalagi untuk kebaikan. Saling mengajak agar selalu disiplin dan kerja keras dalam bekerja. keenam, menciptakan kebiasaan - kebiasaan yang mendukung sikap disiplin dan kerja keras. Seperti saling menghormati jika bertemu, mengikutsertakan karyawan dalam pertemuan yang berhubungan dengan pekerjaan mereka. Memberi tahu walaupun kepada bawahan bila hendak meninggalkan tempat kerja dan untuk urusan apa dan lain sebagainya.

Keenam, sikap individu. Sebenarnya apa yang telah dipaparkan diatas semuanya Kembali pada diri masing - masing yang merupakan bawaan dari lahir. Juga bakat, fisik, kejiwaan dan sifat pribadi.

\section{KESIMPULAN}

Berdasarkan hasil penelitian dan pembahasan yang telah dipaparkan. Maka, dapat diambil kesimpulan sebagai berikut :

1. Budaya disiplin dan kerja keras merupakan hal yang penting karena perusahaan atau koperasi yang berhasil itu sangat dipengaruhi oleh sumber daya manusia yang dia miliki.

2. Cara agar budaya disiplin dan sikap kerja keras dalam bekerja khususnya pada 
lingkungan koperasi dapat dijalankan oleh para pekerja :

a. Pemberian motivasi dan pelatihan.

b. Keteladanan pemimpin.

c. Membuat aturan yang pasti (yang dapat dijadikan pegangan).

d. Adanya pengawasan.

e. Perhatian antar karyawan.

f. Menciptakan kebiasaan - kebiasaan yang mendukung sikap disiplin dan kerja keras.

g. Sikap individu.

\section{REKOMENDASI}

Namun penelitian ini memiliki kekurangan yaitu kurang banyaknya sumber - sumber rujukan yang harus dianalisis dan diteliti tentang minimnya budaya disiplin dan kerja keras dalam bekerja khususnya dalam ruang lingkup koperasi di indonesia pada era industri 4.0 . sehingga dalam penelitian selanjutnya harus memperbanyak sumber - sumber rujukan untuk penelitian.

\section{DAFTAR PUSTAKA}

El Hakim, A.A.F. 2017. Model Peningkatan Pola Kerja Keras Melalui Religiosity, Motivasi Intrinsik Dan Motivasi Ekstrinsik (Pada Pt. Bank Muamalat Indonesia Cabang Kudus). EKOBIS Vol.18, No.2, (Juli), 138- 139.

Hardiansyah, R.O. 2017. Pengaruh Etos Kerja Dan Disiplin Kerja Terhadap Kinerja Pegawai (Studi Pada Pegawai Dinas Pekerjaan Umum Kota Magelang. 2 (Mei), 14-25.

Hartono, R. dan Anshori, M.I. 2019. Peran Kerja Keras Dan Kerja Cerdas Melalui Motivasi Kerja Dalam Meningkatkan Kinerja Karyawan Agent Asuransi. Kompetensi, Vol 13, No 2, (Oktober), 101-103.

Helmi, A.V. 1996. Disiplin Kerja. Buletin Psikologi, (Desember), 33. Kartiningrum, E.D. 2015. Panduan Penyusunan Studi Literatur. 4-5.

Nasir, M. Taufan, R.R. Fadhil, M. dan Syahnur, M.H. 2021. Budaya Organisasi Dan Disiplin Kerja Serta Pengaruhnya Terhadap Kinerja Karyawan. AkMen, Volume 18, 1 (April) 73-74.

Purba, T. dan Heryenzus. Analisis Gagalnya Koperasi Di Kota Batam, 184. Siagian, M. Peranan Disiplin Kerja Dan Kompensasi Dalam Mendeterminasi Kinerja Karyawan Dengan Motivasi Kerja Sebagai Variabel Intervening Pada Pt Cahaya Pulau Pura Di Kota Batam, 24-25.

Sofyan. Jabbar A, A. Sunarti. 2019. Pengaruh Budaya Kerja Terhadap Kedisiplinan Pegawai Di Kantor Desa Bina Baru Kecamatan Kulo Kabupaten Sidenreng Rappang. Jurnal MODERAT, Volume 5, Nomor 1, (Februari), 61-62.

Wadu, L.B. Samawati U. Ladamay, I. 2020. Penerapan Nilai Kerja Keras Dan Tanggung Jawab Dalam Ekstrakurikuler Pramuka Di Sekolah Dasar. Jurnal Bidang Pendidikan Dasar (JBPD), Vol.4 No.1, (Januari), 101-102. 